\title{
Editorial to the special issue on empirical stock-flow consistent models
}

\author{
Gennaro Zezza \\ Università di Cassino e del Lazio Meridionale, Italy and Levy Economics Institute at Bard College, \\ Annandale-on-Hudson, NY, USA
}

The motivation for this special issue originates in our interest for stimulating more empirical, policy-oriented work among heterodox researchers (where by heterodox we refer to economists who do not derive their macroeconomic analysis from the optimizing behaviour of individual agents). More specifically, we aimed at encouraging a methodological discussion among the post-Keynesians who adopt the stock-flow consistent (SFC) approach to macroeconomics with an interest in policy.

The post-Keynesian tradition has for a long time been sceptical of empirical techniques such as time series econometrics - to infer from past data useful information for the future, mainly because of the crucial relevance of Keynes's fundamental uncertainty in determining macroeconomic outcomes. ${ }^{1}$ On the other hand, one of the reasons for the success of the SFC approach depends on the recognition ${ }^{2}$ that empirical models developed by ${ }^{3}-$ or inspired by ${ }^{4}$ the work of - Wynne Godley have been more successful than models from other approaches ${ }^{5}$ in predicting the last recessions, or in tracking some specific economies.

The number of contributions to macroeconomics which adopt the SFC approach is rapidly growing. ${ }^{6}$ Most of the new contributions are theoretical, extending the approach laid out in Godley/Cripps (1983), Godley/Lavoie (2007a) and Dos Santos/Zezza (2008) in different directions. By 'theoretical' contributions we mean models where there is no attempt at fitting model variables to actual data for an economy and parameter values are not obtained by either econometric estimates or calibration for a specified economic system.

But there is also a growing interest in applying the SFC approach to data for a particular country. This was the main interest in Godley's work since the 1970s, when he was analysing the economy of the United Kingdom (see Cripps/Godley 1976), and continued with models for Denmark (see Godley/Zezza 1992), and later for the United States, when he moved to the Levy Economics Institute, USA. ${ }^{7}$

1. See Davidson (1991) for a classical reference, although we do not wish to address this literature in further detail here.

2. See Bezemer (2010) among others.

3. See Lavoie/Zezza (2012) for a complete list of Godley's publications.

4. The Levy Institute research team on 'The State of the US and World Economies' has continued to maintain Godley's model for the US economy, as well as developing similar models for other countries. See Papadimitriou et al. (2013a; 2013b) for Greece.

5. See Bezemer (2010), who identifies Godley/Zezza (2006) and Godley et al. (2007) as timely warnings of the 2007 recession.

6. See Nikiforos/Zezza (2017) for a recent survey.

7. Godley (1999) is considered to be the contribution which brought attention to the SFC approach in recent times, since it projected the 2001 recession in a timely manner, at a time when commentators were praising the 'Great Moderation' and the end of business cycles. Godley's empirical work on the US has been published in the Levy Institute Strategic Analysis series. 
At present, SFC models have been developed for many countries. Apart from those already mentioned, developed by Godley and his associates, there are now models for Argentina (Valdecantos 2012), Austria (Miess/Schmelzer 2016a; 2016b), Colombia (Escobar-Espinoza 2016), Denmark (Kiel 2018), Greece (Papadimitriou et al. 2013a), Iceland (Raza et al. 2019), Ireland (Kinsella/Aliti 2013), Italy (Zezza 2018; Passarella 2019), Moldova (Le Heron/Yol 2019), South Africa (Makrelov et al. 2018) and the United Kingdom (Burgess et al. 2016).

Given the growing interest in this topic, we organized a call for papers for a session on empirical SFC models at the 21st Conference of the Forum for Macroeconomics and Macroeconomic Policies (FMM) which was held in Berlin, 9-11 November 2017. ${ }^{8}$ In this special issue we publish a selection of the contributions to the two sessions from the conference.

The paper by Edwin Le Heron and Nicolas Yol focuses on the role of remittances in a small country, Moldova, which experienced substantial migration, and where remittances are therefore a relevant contribution to the disposable income of the private sector. The authors build a post-Keynesian open-economy SFC model, following Godley/Lavoie (2007b), Lavoie/Zhao (2010), Le Heron (2011) and Le Heron/Marouane (2019). Model parameters are taken from other models in the literature, or calibrated on the basis of country data. The authors use the model for simulating how Moldova would be affected by a downturn in the income of the countries where most of the migrants are located (Europe and Russia), which also happen to be the main destination for Moldova's exports. Model simulations show the relevance of external shocks not only on household consumption, but also on investment, remittances being a major channel of transmission. We believe that their model provides a useful starting point for analysing the economies of other countries with similar features.

The paper by Marco Veronese Passarella is aimed at providing a step-by-step introductory guide for building a simple empirical stock-flow model for a given country. The author discusses the use of different software applications for different purposes: building on the work of Antoine Godin, ${ }^{9}$ already available R code can be adapted to a specific (European) country to obtain relevant time-series data from Eurostat, which can then be passed to the EViews software for model building. Passarella illustrates the procedures by discussing a model of the Italian economy, loosely based on the model in Burgess et al. (2016). Model parameters are either estimated with simple econometric approaches, calibrated from Italian data, or taken from the literature. The author briefly discusses the problem of model validation against historical data, and then provides some useful hints on how to set up policy scenarios.

In their contribution, Hamid Raza, Bjorn Runar Gudmundsson, Gylfi Zoega and Mikael Randrup Byrialsen develop a model tailored to Iceland, with the aim of assessing the role of the volatility of capital inflows for a small country with its own currency. The authors build on previous theoretical models for a small open economy already available in the literature, where therefore it can be safely assumed that developments in the economy do not have a sensible impact on the rest of the world, so that the complications of a twocountry model like the one in Godley/Lavoie (2007a: ch. 12) can be neglected. The model is tailored to Iceland, specifically by assuming that domestic banks also have foreign branches which attract foreign deposits. The authors use the model to simulate the consequences of a sudden stop in foreign lending, and study the implications of the introduction of capital controls. As such, the model can be used as a starting point for analysing similar small economies which rely on foreign credit.

Finally, Gennaro Zezza and Francesco Zezza discuss the modelling strategy for developing an empirical SFC model for a whole country. While Passarella (2019: 56) seems to

8. Materials are available at https://www.boeckler.de/veranstaltung_imk_107484.htm.

9. See https://github.com/antoinegodin. 
suggest that a model based on the same (Eurostat) data source 'can be replicated for other countries', the authors stress the relevance of the institutional features of the economy under study, which can be derived, among other things, from a careful analysis of sectoral balance sheets and flow of funds, which may point to different solutions for the degree of complexity, and on how (and whether) to consolidate some sectors to reduce the complexity of the model. They provide examples related to Greece and Italy, briefly discussing the need to integrate different sources of data when the model needs to describe the behaviour of the central bank in the European Monetary Union.

\section{REFERENCES}

Bezemer, D.J. (2010): Understanding financial crisis through accounting models, in: Accounting, Organizations and Society, 35(7), 676-688.

Burgess, S., Burrows, O., Godin, A., Kinsella, S., Millard, S. (2016): A dynamic model of financial balances for the United Kingdom, Bank of England Staff Working Paper No 614, September.

Cripps, F.T., Godley, W. (1976): A formal analysis of the Cambridge Economic Policy Group Model, in: Economica, 43(172), 335-348.

Davidson, P. (1991): Is probability theory relevant for uncertainty? A Post Keynesian perspective, in: Journal of Economic Perspectives, 5(1), 129-143.

Dos Santos, C.H., Zezza, G. (2008): A simplified, 'benchmark', stock-flow consistent post-Keynesian growth model, in: Metroeconomica, 59(3), 441-478.

Escobar-Espinoza, A. (2016): Stock-flow consistent models for developing countries: the case of Colombia, Paper Presented at the 19th Annual Conference on Global Economic Analysis, Washington, DC.

Godley, W. (1999): Seven unsustainable processes: medium-term prospects and policies for the United States and the world, Levy Economics Institute.

Godley, W., Cripps, F.T. (1983): Macroeconomics, London: Oxford University Press.

Godley, W., Lavoie, M. (2007a): Monetary Economics: An Integrated Approach to Credit, Money, Income, Production and Wealth, Basingstoke, UK: Palgrave Macmillan.

Godley, W., Lavoie, M. (2007b): A simple model of three economies with two currencies: the eurozone and the USA, in: Cambridge Journal of Economics, 31(1), 1-23.

Godley, W., Zezza, G. (1992): A simple stock flow model of the Danish economy, in: Brink, H. (ed.), Themes in Modern Macroeconomics, London: Palgrave Macmillan, 140-179.

Godley, W., Zezza, G. (2006): Debt and lending: a cri de coeur, Levy Economics Institute Policy Note 4, 6.

Godley, W., Papadimitriou, D.B., Hannsgen, G., Zezza, G. (2007): The U.S. economy: is there a way out of the woods?, Levy Institute Strategic Analysis.

Kiel, F. (2018): A Stock Flow Consistent Empirical Model of the Danish Economy, Master Thesis, Aalborg University.

Kinsella, S., Aliti, G.T.-T. (2013): Modeling moments of crisis: the case of Ireland, in: Journal of Economic Issues, 47(2), 561-566.

Lavoie, M., Zezza, G. (eds) (2012): The Stock-Flow Consistent Approach: Selected Writings of Wynne Godley, Basingstoke, UK: Palgrave Macmillan.

Lavoie, M., Zhao, J. (2010): A study of the diversification of China's foreign reserves in a threecountry stock-flow consistent model, in: Metroeconomica, 61(3), 558-592.

Le Heron, E. (2011): Confidence and financial crisis in a post-Keynesian stock flow consistent model, in: European Journal of Economics and Economic Policies: Intervention, 8(2), 361-387.

Le Heron, E., Marouane, A. (2019): Chocs politiques et croissance economique: perspectives pour la Tunisie, in: Economie appliquée, (1), forthcoming.

Le Heron, E., Yol, N. (2019): The macroeconomic effects of migrants' remittances in Moldova: a stock-flow consistent model, in: European Journal of Economics and Economic Policies: Intervention, 16(1), 31-54. 
Makrelov, K., Arndt, C., Davies, R., Harris, L. (2018): Stock-and-flow-consistent macroeconomic model for South Africa, World Institute for Development Economic Research (UNU-WIDER), Working Paper No 7.

Miess, M.G., Schmelzer, S. (2016a): Stock-flow consistent modelling of real-financial cycles and balance sheet dynamics, Preliminary Work-in-Progress Version for 13th EUROFRAME Conference, Utrecht, the Netherlands, 10 June.

Miess, M., Schmelzer, S. (2016b): Extension of the empirical stock-flow consistent (SFC) model for Austria, Vienna, Institute for Advanced Studies, Research report.

Nikiforos, M., Zezza, G. (2017): Stock-flow-consistent macroeconomic models: a survey, in: Journal of Economic Surveys, 31(5), 1204-1239.

Papadimitriou, D.B., Nikiforos, M., Zezza, G. (2013a): A Levy Institute model for Greece, Levy Institute, Technical report.

Papadimitriou, D.B., Nikiforos, M., Zezza, G. (2013b): The Greek economic crisis and the experience of austerity: a strategic analysis, Levy Institute Strategic Analysis.

Passarella, M.V. (2019): From abstract to concrete: some tips for developing an empirical stock-flow consistent model, in: European Journal of Economics and Economic Policies: Intervention, 16(1), 55-93.

Raza, H., Gudmundsson, B.R., Zoega, G., Randrup Byrialsen, M. (2019): Crises and capital controls in small open economies: a stock-flow consistent approach, in: European Journal of Economics and Economic Policies: Intervention, 16(1), 94-133.

Valdecantos, S. (2012): Macroeconomic dynamics in Argentina in the light of a structuralist post Keynesian stock-flow consistent model, Paper Presented at V Jornadas de Economia Critica, Buenos Aires, August.

Zezza, F. (2018): Stock-Flow Consistent Macroeconomic Models: Theory, Practice and Applications, $\mathrm{PhD}$ Thesis, University of Siena.

Zezza, G., Zezza, F. (2019): On the design of empirical stock-flow consistent models, in: European Journal of Economics and Economic Policies: Intervention, 16(1), 134-158. 